Jurnal Ilmu Sosial dan Pendidikan (JISIP)

Vol. 5 No. 3 Juli 2021

Terakreditasi Peringkat 5 (No. SK: 85/M/KPT/2020)

e-ISSN : 2656-6753, p-ISSN: 2598-9944

DOI: 10.36312/jisip.v5i3.2187/http://ejournal.mandalanursa.org/index.php/JISIP/index

\title{
Penerapan Metode Sosiodrama Dalam Keterampilan Berbicara Siswa Kelas IV Pada Pembelajaran Bahasa Indonesia Di MI Muhammadiyah Sinduraja
}

\author{
Nur Hidayah', Abdul Wachid BS ${ }^{2}$, Tutuk Ningsih ${ }^{3}$ \\ ${ }^{1,2)}$ UIN Prof.KH.Saifuddin Zuhri \\ ${ }^{1)}$ Email: nhnunung647@.gmail.com ${ }^{1}$, abdulwachidbs@iainpurwokerto.ac.id ${ }^{2}$, \\ tutuk@iainpurwokerto.ac.id ${ }^{3}$
}

\begin{abstract}
Article Info
Abstract

Students' speaking skills always require practice and also the right encouragement

Article history: by the teacher. This is where the teacher as a person who has maturity in thinking should build a replication of activities and learning in the classroom as needed by students. This research is an action study of classroom action. The subjects of this study were fifth grade students at MI Muhammadiyah Sinduraja. The sociodrama method was carried out, the researchers obtained data on the percentage of good progress to improve students' speaking skills. The percentage which was originally shown at 60\% had an increase to $75 \%$ when the action test was carried out in the

Keywords: second cycle.
\end{abstract}

Metode sosiodrama,

keterampilan berbicara

\section{Article Info}

Article history:

Article Accepted: 12 July 2021

Publication : 16 July 2021

Keywords:

Sociodrama Method, Speaking

Skill

\begin{abstract}
Abstrak
Keterampilan berbicara siswa selalu memerlukan latihan dan juga dorongan yang tepat oleh guru. Di sinilah guru sebagai orang yang memiliki kematangan dalam berpikir sebaiknya membangun replikasi aktivitas dan pembelajaran di ruang kelas sesuai yang dibutuhkan siswa. Penelitian ini merupakan tindakan kajian tindakan kelas. Subjek dari kajian ini adalah siswa kelas V di MI Muhammadiyah Sinduraja Metode sosiodrama yang dilakukan, peneliti memperoleh data prosentasi kemajuan yang baik untuk meningkatkan kemampuan berbicara siswa. Prosentasi yang semula ditunjukkan pada angka $60 \%$ memiliki kenaikan menjadi $75 \%$ saat dilakukan uji tindakan pada siklus tahap II.

This is an open access article under the Lisensi Creative Commons Atribusi-BerbagiSerupa 4.0 Internasional
\end{abstract}

Corresponding Author:

Nur Hidayah

1,2) UIN Prof.KH.Saifuddin Zuhri

Email: nhnunung647@.gmail.com

\section{PENDAHULUAN}

Kemampuan berbicara menjadi hal yang tentu harus diperhatikan mengingat hal itu menjadi bekal masa depan. Interaksi yang dilakukan anak-anak saat ini dapat dilihat memiliki kepasifan yang mengkhawatirkan. Penyebabnya bisa berupa ketidakpercayaan diri yang tertanam pada diri anak. Hal lainnya yang dapat terjadi juga adalah kurang terampilnya anak dalam mengeluarkan gagasan yang berada di dalam pikiran menjadi sebuah pembicaraan.

Tarigan (2008) memberikan pandangan bahwa anak melakukan aktivitas berbicara terlebih dahulu sebelum ia menulis. Meskipun pada umumnya, berbicara sebagai aktivitas lisan pada 
umumnya selalu berubah dan tidak selalu tetap. Bahkan terkadang lebih membingungkan serta tidak sistematis dari pada tulisan. Persiapan seseorang dalam berbicara memang kerap kacau dan terjadi penyusunan kalimat yang tidak memiliki relevansi.

- Di sinilah pentingnya kebiasaan dan langkah praktis yang mendukung anak untuk mengembangkan kemampuan berbicaranya. Kemahiran berbicara anak harus ditingkatkan dan diperhatikan sedini mungkin. Dengan begitu, anak akan memiliki kepercayaan diri yang tinggi serta memiliki keaktifan baik di ruang kelas atau lingkungan masyarakat di sekitarnya.

Sosiodrama merupakan salah satu aktivitas yang melibatkan kemampuan berbicara. Sosiodrama menjadi salah satu penyajian materi yang disampaikan melalui lisan dengan bentuk sebuah pertunjukkan. Putra (2012) mengatakan bahwa drama sebagai perantara untuk menyalurkan seni dan hiburan. Winkel (2012) menyebut sosiodrama sebagai dramatisasi beragam persoalan yang ada di permukaan sosial masyarakat. PPelaksanaan pada aktivitas ini juga memberikan kondisi iklim yang mengandung sebuah persoalan sehingga siswa merasa untuk berupaya memecahkannya (Susiastuti, 2019)

Sosiodrama sebagai sebuah pertunjukkan dan tontonan yang menarik memiliki minat siswa yang tinggi. Hal inilah yang menjadikan sosiodrama untuk menyumbang beragam keterampilan pada siswa. Tulisan Tri Hardini yang berjudul Peningkatan Keaktifan dan Hasil Belajar Siswa dalam Pembelajaran PKN Melalui Metode Sosiodrama di Kelas 5 SD Tlompakan 01 - Tuntang memiliki kesamaan pada kajian mengenai metode sosiodrama. Hanya saja tulisan tersebut bertujuan untuk meningkatkan keaktifan dan hasil belajar siswa. Kajian tersebut menghasil prosesntasi peningkatan yang memuaskan atas metode sosiodrama yang digunakan. Penulis bermaksud untuk mengkaji Metode Sosiodrana dalam Peningkatan Keterampilan Berbicara di MI Muhammadiyah Sinduraja.

\section{KAJIAN TEORI}

\subsection{Metode Sosiodrama}

Drama memiliki pengertian berbuat, bertindak dan bagaimana berlaku. Konsep drama ini juga bertujuan untuk memberikan hiburan. Meskipun dalam pada pengertiannya, drama memiliki arti yang lebih luas. Putra (2012) mengatakan bahwa drama sebagai perantara untuk menyalurkan seni dan hiburan. Winkel (2012) menyebut sosiodrama sebagai dramatisasi beragam persoalan yang ada di permukaan social masyarakat. Sosio dan drama adalah permulaan kata terpisah yang tergabung menjadi sosio drama. Aktivitas social yang ditunjukkan di masyarakat dan menjadi sebuah tontonan inilah yang kemudian mengacu pada kata 'Sosio'. Marno (2010) Interaksi dan hubungan social yang terjadi sebagai kebutuhan inilah yang membentuk sebuah masyarakat.

Pramata menyebut (2018) penyajian dan penampilan, pertunjukkan serta uraian yang digunakan masyarakat dilakukan menjadi sebuah pengertian 'sosiodrama'. Maka dapat disebut pula, bahwa sosiodrama menjadi upaya pemecahan persoalan yang terjadi pada lingkungan social. Persoalan yang muncul seperti keretakan di dalam keluarga, pecandu narkoba bahkan persoalan remaja. Aktivitas ini juga menjadi sebuah pengalaman nyata yang memberikan refleksi yang memantik kesadaran sebab dilakukan dengan melibatkan secara langsung pada peserta didik (Ismail, 2019). Penggunaan sosiodrama saat ini juga menjadi pemberian siswa untuk mampu menghayati persoalan social dan mengupayakan pemecahannya. Sanjaya (2012) memberikan penjelasan peran sosiodrama yang ekspresif dapat memberikan penghayatan yang dilakukan dengan bebas dan secara lisan menjadi sebuah suasana yang dapat dihayati. Dengan begitu, pada pengajaran bahasa. Kualitas dan proses pengajarannya menjadi lebih optimal. Metode ini dianggap memiliki kelebihan agar siswa dalam mengeksplorasi lebih dalam sehingga menjadi pendidikan moral yang tepat. 
Daya tarik dan menyenangkan yang ada pada metode sosiodrama inilah yang menjadi salah satu cara untuk mengembangkan kemampuan berbicara yang dilakukan dengan aktivitas dialog. Aktivitas ini menjadi stimulus yang memberikan peningkatan kemampuan berbicara Pelaksanaan pada aktivitas ini juga memberikan kondisi iklim yang mengandung sebuah persoalan sehingga siswa merasa untuk berupaya memecahkannya (Susiastuti, 2019) Sosiodrama sebagai sebuah pertunjukkan dan tontonan yang menarik memiliki minat siswa yang tinggi. Hal inilah yang menjadikan sosiodrama untuk menyumbang beragam keterampilan pada siswa. Salah satu yang paling lekat pada metode ini adalah keterkaitannya pada pembelajan berbahasa yakni kemampuan berbicara.

Ramayulis (2010) menjelaskan langkah sosiodrama di antaranya:

1. Persiapan

Pada langkah ini, guru memberikan standar dan membuat persoalan social yang sudah ditetukan. Pemeran yang diambil dari peserta didik inilah yang kemudian dipilih guru agar dapat dipersiapkan dan dipelajari. Adapun peran yang akan diperagakan ditentukan temanya terlebih dahulu untuk membangun cerita. Dalam hal ini, guru juga menjelaskan mengenai jenis peran dan bagaimana pelaksanannya di dalamnya.

2. Penentuan pelaku atau pemeran.

Guru mendorong siswa untuk bermain peran dan melakukan pemilihan peran yang dianggap guru sesuai. Guru dapat memberikan petunjuk bagaimana peran dilakukan.

3. Permaian sosiodrama.

Pemeran selanjutnya memberikan peragaan yang berasal dari imajinasi dan tanggap peran masing-masing hingga klimaks sehingga menjadi penghayatan mendalam

4. Diskusi

Setelah dilakukan peran peragaan. Pemeran kemudian mendikusikan tema dan perilaku yang sesuai dengan tema cerita agar memperoleh dialog dan tanggapan dan sebuah kesimpulan

5. Ulangan permainan.

Hasil diskusi inilah yang kemudian menjadi acuan untuk pemeran saat dilakukan pementasan kembali

2.2.Keterampilan Berbicara

Kemampuan berbicara menjadi salah satu pembahasan dan tuntutan kemampuan di dalam pembelajaran bahasa (Merera, 2019). Tidak dapat dipungkiri, berbahasa memang memuat kemampuan berbicara. Situasi yang baik dan komunikatif tentu dibangun dengan kemampuan berbicara dan bahasa yang baik. Dengan begitu, keduanya memiliki relevansi atau hubungan yang memang selalu terkait. Abidin (2012) menjelaskan tujuan berbicara sebagai cita-cita untuk memperoleh komunikasi yang baik dan wajar.

\section{METODE PENELITIAN}

Kajian ini menggunakan penelitian tindakan kelas dengan penggunaan tahap bersiklus. Pada tiap siklus terdiri dari empat tahap di antaranya; Perencanaan, Pelaksanaan, Observasi dan Refleksi. Pada pengumpulan data dilaksanakan di MI Muhammadiyah Sinduraja dengan subjek kelas IV.

Pengumpulan data pada kajian ini dilaksanakan dengan penilaian dan catatan lapangan. Terdapat dua jenis yang diperoleh dari kajian ini yaitu kualitatif dan kuantitatif. Ketuntasan siswa ditandai dengan prosentasi yang dicapai sebanyak 70\%. Dengan begitu, siswa yang mencapai hasil tersebut maka sudah mencapai ketuntasan dengan baik.

\section{HASIL DAN PEMBAHASAN}

Aktivitas metode sosiodrama yang dilakukan di MI Muhammadiyah Sinduraja, Purbalingga dengan pembatasan subjek pada siswa kelas IV menunjukkan peningkatan pemerolehan capaian 
belajar yang baik. Kemampuan berbicara pada siswa dalam peningkatannya harus memiliki dorongan berupa formula dan strategi yang mapan untuk siswa. Dari capaian belajar yang didapatkan penulis, sosiodrama menjadi aktivitas sekaligus metode yang efektif untuk meningkatkan kemahiran berbicara siswa. Prosentasi peningkatan tersebut ditandai dengan capaian belajar siswa sejak semester I hingga pada dilakukannya aktivitas dan uji tindakan siklus II.

Data sebelumnya yang tidak mencapai ketuntasan belajar siswa dengan prosentasi yang belum pada angka 50\%. Di sinilah, penulis kemudian bermaksud untuk mengkaji capaian hasil belajar melalui metode sosiodrama untuk peningkatan kemampuan berbicara pada siswa kelas IV. Aktivitas sosiodrama yang dilakukan guru dan siswa memberikan hasil yang meningkat dan mencapai ketuntasan dalam pembelajaran. Dari data yang peneliti rumuskan dan peroleh. Pada uiji tindakan siklus pertama, siswa baru mencapai prosentasi 65. Oleh karena, metode ini memiliki peningkatan dari sebelumnya.

Peneliti kemudian melanjutkan pada siklus kedua dan memberikan hasil yang meningkat dengan prosentasi sebanyak 75\%. Dengan begitu, metode ini cukup baik untuk digunakan pada siswa dalam memberikan perkembangan dan tingkat kemampuan berbicaranya. Meskipun begitu, memang terdapat siswa yang belum mencapai hasil yang maksimal. Hal itu dikarenakan kemampuan daya siswa yang memang tergolong rendah dari yang lainnya. Dengan begitu, guru memiliki kesempatan untuk dapat memperbaiki dan memberikan motivasi yang lebih pada siswa yang memang memiliki daya serap rendah.

\begin{tabular}{|c|c|c|c|c|c|c|}
\hline \multirow[t]{2}{*}{ No } & \multirow[t]{2}{*}{ Nama } & \multirow[t]{2}{*}{ KKM } & \multicolumn{3}{|c|}{ Hasil Evaluasi } & \multirow[t]{2}{*}{ Ket. } \\
\hline & & & Para Siklus & Siklus I & Siklus II & \\
\hline 1 & Afif Labib Mubarok & 65 & 65 & 75 & 80 & Naik \\
\hline 2 & Ahmad Khoirul Anam & 65 & 60 & 65 & 70 & Naik \\
\hline 3 & Angga Saputra & 65 & 65 & 70 & 80 & Naik \\
\hline 4 & Aziz Bayu Pangestu & 65 & 70 & 80 & 90 & Naik \\
\hline 5 & Farel Aldiansyah & 65 & 60 & 65 & 70 & Naik \\
\hline 6 & Felisa Nur Hidayah & 65 & 40 & 50 & 50 & Tetap \\
\hline 7 & Ghufron Eka Saputra & 65 & 50 & 60 & 70 & Naik \\
\hline 8 & Irsyad Hanan Imaniar & 65 & 70 & 80 & 85 & Naik \\
\hline 9 & Latifa Amalia & 65 & 60 & 60 & 65 & Naik \\
\hline \multirow[t]{7}{*}{10} & Melista Catur Septiyani & 65 & 60 & 60 & 65 & \multirow[t]{7}{*}{ Naik } \\
\hline & Nilai Terendah & & 40 & 50 & 50 & \\
\hline & Nilai Tertinggi & & 70 & 80 & 90 & \\
\hline & KKM $\leq 65$ & & 6 & 4 & 8 & \\
\hline & $K K M \geq 65$ & & 4 & 6 & 1 & \\
\hline & Total Nilai & & 600 & 665 & 725 & \\
\hline & Nilai Rata-rata & & 60 & 66,5 & 72,5 & \\
\hline
\end{tabular}

\section{SIMPULAN}

Berdasarkan hasil pembahasan yang telah disajikan diatas, metode sosiodrama dapat dijadikan sebagai suatu metode pembelajaran bahasa khususnya bahasa Indonesia. Pada metode ini, tentu dapat memberikan kesempatan pada peserta didik untuk dapat bereksplorasi sesuai dengan peran yang diberikan oleh guru. Hal ini tentunya, akan membuat mereka dengan leluasa berbicara dan sangat mendukung untuk keterampilan berbicara setiap peserta didik. Selain itu dapat menambah penguasaan kosakata peserta didik dalam berbicara seperti mengungkapkan pendapatnya.

Selain mengajarkan bagaimana penguasaan kosakata yang memadai, keterampilan berbicara juga membutuhkan keaktifan siswa untuk mempraktikannya. Hal ini berkaitan erat dengan rasa percaya diri pada saat berkomunikasi, sebab pada saat berbicara seseorang membutuhkan suara dan 
praktik yang benar. Dalam berkomunikasi, juga dibutuhkan budaya dan norma dalam bahasa itu sendiri, sehingga metode sosiodrama sangat sesuai untuk diaplikasikan dalam pembelajaran keterampilan berbicara.

\section{DAFTAR PUSTAKA}

Abidin, Y. (2012). Pembelajaran Membaca Berbasis Pendidikan Karakter. Bandung: Refika Aditama.

Chaer, Abdul. (2013). Linguistik Umum. Jakarta: Rhineka Cipta.

Ismail, Ahmad. 2019. Metode Sosiodrama untuk Meningkatkan Kemampuan Bahasa Arab Siswa Madrasah Aliyah. UIN Walisongo Semarang

Marno dan Idris, M. Strategi dan Metode Pengajaran: Menciptakan Keterampilan Mengajar yang Efektif dan Edukatif. Yogyakarta: Ar-Ruzz Media.

Merera, Riana Esa. 2019. Penggunaan Model Sosiodrama dalamKeterampilan Berbicara Siswa pada Pembelajaran Bahasa Indonesia. Universitas Majalengka. 1-6

Pratama, Novan Dymas, dkk. 2018. Penggunaan Metode Sosiodrama dalam Pembelajaran Keterampilan Berbicara Bahasa Arab. Universitas Islam Negeri Maulana Malik Ibrahim Malang.

Ramayulis. (2010). Metodologi Pendidikan Agama Islam. Jakarta: Kalam Mulia.

Sanjaya, Wina. (2012). Strategi Pembelajaran Berorientasi Standar Proses Pendidikan. Jakarta: Kencana Prenada Media Group.

Susiati. 2019. Pengaplikasian Metode Sosiodrama dalam Pembelajaran. Universitas Iqra Buru Tarigan, H. G. (1994). Berbicara Sebagai Suatu Keterampilan. Bandung: Angkasa.

Winkel, W.S. (2012). Bimbingan dan Konseling di Institusi Pendidikan. Yogyakarta : Media Abadi 